\title{
The plasma membrane as a combat zone in the HIV battlefield
}

\author{
Robert W. Doms ${ }^{1}$ and Didier Trono ${ }^{2,3}$ \\ ${ }^{1}$ Department of Pathology and Laboratory Medicine, University of Pennsylvania, Philadelphia, Pennsylvania 19104, USA; \\ ${ }^{2}$ Department of Genetics and Microbiology, Faculty of Medicine, University of Geneva, CMU, 1211 Geneva 4, Switzerland
}

In the life of a cell, the plasma membrane fulfills a range of functions that go far beyond the shaping and maintenance of architectural features and the absorption of nutrients. The plasma membrane is a highly sophisticated structure whose phospholipidic backbone is loaded with proteins responsible for channeling the stream of information that continuously flows between a cell and its environment. Although the nucleus can intuitively be viewed as the cell's center of command, the translation of its genetic content is constantly modulated by signals triggered and often integrated at the level of the plasma membrane. Reciprocally, the cell exposes on or releases from its surface a wide variety of molecules that regulate its recognition by other cells and that sometimes influence the homeostasis of the whole organism.

The plasma membrane is also the site where intracellular pathogens first clash with their target and the place from which the immune system is subsequently called to the rescue. Correspondingly, the study of viruses has provided great strides in the comprehension of such fundamental processes as membrane fusion, protein transport, endocytosis, signal transduction, and antigen presentation, all phenomena that are intimately intertwined with the biology of membranes and their associated proteins. Recent progress in the analysis of the HIV, probably by now the most extensively characterized of all human pathogens, provides a good illustration of this paradigm. Just as the composition of the plasma membrane influences viral infectivity, the virus in turn uses components of the plasma membrane that are to its advantage and modifies others to suit its purposes. The interplay between HIV and the plasma membrane has much to offer in terms of understanding viral tropism and pathogenicity and normal cellular functions, and for developing new antiviral approaches.

\section{Fancy break in: viral entry}

To infect a cell, a membrane-enveloped virus such as HIV must transfer its genome across both the viral and

${ }^{3}$ Corresponding author.

E-MAIL didier.trono@medecine.unige.ch; FAX 41-22-702-5721.

Article and publication are at www.genesdev.org/cgi/doi/10.1101/ $\operatorname{gad} .833300$. cellular membranes-not a trivial task given the inherent stability of biological membranes. Enveloped viruses accomplish this feat by encoding and expressing on their surface integral membrane proteins that, under the right conditions, undergo conformational changes that cause the viral and cellular membranes to fuse with one another, providing a portal of entry (Hernandez et al. 1996). The entry process can be divided into three components: attachment of the virus to the cell surface, involving recognition and binding to specific cell surface receptors; a triggering event that causes the viral fusion protein to undergo conformational changes; and the membrane fusion reaction itself. The presence or absence of molecules on the cell surface necessary for attachment and triggering greatly influences viral tropism: the ability of a given virus to infect only specific cell types.

\section{First contact}

The HIV-1 envelope (Env) protein is a type I integral membrane protein that mediates viral attachment and membrane fusion and is also the target for neutralizing antibodies. Synthesized as a single polypeptide precursor that forms trimers, Env is subsequently cleaved by a cellular protease to generate two noncovalently associated subunits, gp120 and gp41. The gp120 binds virus to the cell surface, whereas the membrane-spanning gp41 subunit is largely responsible for membrane fusion (Wyatt and Sodroski 1998). The primary receptor for HIV-1 is CD4, explaining the propensity of this virus to infect certain $\mathrm{T}$ cells and macrophages, ultimately leading to immune dysfunction. Although CD4 binding is a prerequisite for HIV-1 entry, attachment of virus per se may be mediated by an impressive list of molecules that may serve to concentrate virus on the cell surface and increase the frequency of Env-receptor interactions. The most striking example of an attachment molecule is DCSIGN, a type II membrane protein with a mannose-binding, C-type lectin domain found on some types of dendritic cells (DCs) (Geijtenbeek et al. 2000a,b). DC-SIGN captures HIV-1 to the surface of the DC, retaining it in a native, infectious form that can be efficiently presented to permissive CD4-positive $\mathrm{T}$ cells, resulting in enhanced infection (Geijtenbeek et al. 2000a). DC-SIGN 
does not appear to mediate virus entry or to influence the dependence of virus infection on CD4, but rather increases the efficiency of the process. This interaction may be particularly important in mucosal transmission, with virus being efficiently captured by DC-SIGN-positive subepithelial DCs and ferried to lymphoid tissue where permissive target cells abound. If so, DC-SIGN itself could be a therapeutic target, and if the structural features underlying its ability to bind Env are clarified, this property could be used to advantage in generating subunit vaccines that might be efficiently captured by DC-SIGN, retained in a native state, and presented to B cells. Whether virus-binding proteins exist on other cell types, such as macrophages, is not clear, but their presence could render cells expressing low levels of receptor more permissive to viral entry.

\section{Coreceptor engagement}

Binding of the gp120 subunit to CD4 by itself does not trigger membrane fusion (Maddon et al. 1986; Ashorn et al. 1990; Chesebro et al. 1990; Clapham et al. 1991). However, CD4 binding causes conformational changes in gp120 that enable it to bind to a second receptor, termed a coreceptor, and it is this second receptor binding event that leads to membrane fusion (Lapham et al. 1996; Trkola et al. 1996; Wu et al. 1996). Most primary HIV-1 strains use the chemokine receptor CCR5 in conjunction with CD4 for virus entry (termed R5 virus strains; Berger et al.1998; Doms and Moore 1998) and in absence of CCR 5 because the $\Delta 32$-ccr5 polymorphism is associated with an impressive degree of resistance to virus infection (Dean et al. 1996; Liu et al. 1996; Samson et al. 1996). In some individuals, viruses evolve to use a related receptor, CXCR4, either in place of (X4 virus strains) or in addition to CCR5 (R5X4 strains). Emergence of $\mathrm{X} 4$ virus types is associated with accelerated progression to AIDS (for review, see Miedema et al. 1994). In addition to CCR5 and CXCR4, a host of alternative coreceptors have been identified that enable smaller numbers of HIV strains to infect cells (Berger et al. 1999), but their in vivo relevance is for the most part questionable. Potentially, use of receptors other than CCR5 and CXCR4 could enable virus to infect different cell types and could provide an evolutionary escape route for the virus if effective small molecule inhibitors of the major coreceptors are developed.

Identification of the cell surface receptors to which HIV-1 Env binds and of the conformational changes in Env that ensue have provided great explicatory power for understanding viral tropism and pathogenesis and have identified novel viral and cellular targets for antiretroviral agents. Coreceptor choice is largely governed by variable regions within the gp120 subunit, notably the V3loop and, to a lesser degree, the $\mathrm{V} 1 / 2$ region (Choe et al. 1996; Bieniasz and Cullen 1998; Cho et al. 1998; Hoffman and Doms 1998; Hoffman et al. 1998). However, the fact that so many divergent virus strains use CCR5 argues for the presence of a conserved coreceptor binding region in Env. The recently solved structure of a gp120 core fragment complexed with CD4 reveals the presence of an extraordinarily well conserved region in the bridging sheet, a portion of gp120 that lies between the base of the V3 and V1/2 regions, that is involved in coreceptor binding (Kwong et al. 1998; Rizzuto et al. 1998). That this highly conserved region may be the target for neutralizing antibodies is suggested by the fact that primary SIV (simian immunodeficiency virus) and HIV-2 strains often show at least some degree of CD4-independence, being able to infect cells expressing coreceptor alone (Edinger et al. 1997b; Reeves et al. 1999). The ability of SIV strains to use CCR5 to infect cells independently of CD4 suggests that CCR5 was the primordial receptor for the primate lentiviruses, with the ability to use CD4 evolving later (Edinger et al. 1997b; Martin et al. 1997). It is interesting to note that CD4-independent viruses are invariably neutralization sensitive, perhaps because of constitutive exposure of the coreceptor binding site in gp120 (Hoffman et al. 1999). By acquiring the ability to use CD4, this conserved region can be sequestered until immediately before viral entry, minimizing the time during which it is exposed. This also suggests that genetically triggering Env to become CD4-independent could result in better exposure of conserved neutralizing domains and, perhaps, a more robust humoral response. Indeed, several modified forms of SIV and HIV-1 Env have shown promise as immunogens (Reitter et al. 1998; LaCasse et al. 1999).

\section{Fusion}

It is not clear how binding of coreceptor to gp120 transmits information to gp41, causing it to elicit membrane fusion, although the structural changes undergone by gp41 are increasingly well understood. On coreceptor triggering, the hydrophobic amino-terminal fusion peptide of gp41 is exposed and likely interacts with the membrane of the target cell through the formation of a triple-stranded coiled-coil, effectively bridging the two membranes. The coiled-coil structure, composed of one amino-terminal leucine/isoleucine heptad repeat domain from each Env subunit, contains hydrophobic grooves into which the carboxy-terminal heptad repeat regions of each gp41 subunit pack, thus forming a sixhelix bundle (Fig. 1; Chan et al. 1997; Weissenhorn et al. 1997). Formation of the six-helix bundle is rate-limiting for fusion, and the change in free energy on its formation is sufficient to form a fusion pore (Melikyan et al. 2000). This fusion mechanism is shared by many other viral fusion proteins, including those from influenza, Ebola virus, and paramyxoviruses, all of which form similar six-helix bundles that bring the fusion peptide (and the cellular membrane) in close proximity to the transmembrane domain (and the viral membrane) (for review, see Chan and Kim 1998; Skehel and Wiley 1998). Similar mechanisms may be used by cellular proteins that mediate intracellular membrane fusion events (Poirier et al. 1998; Sutton et al. 1998).

Formation of the six-helix bundle can be inhibited by addition of peptides based on the gp41 carboxy-terminal 


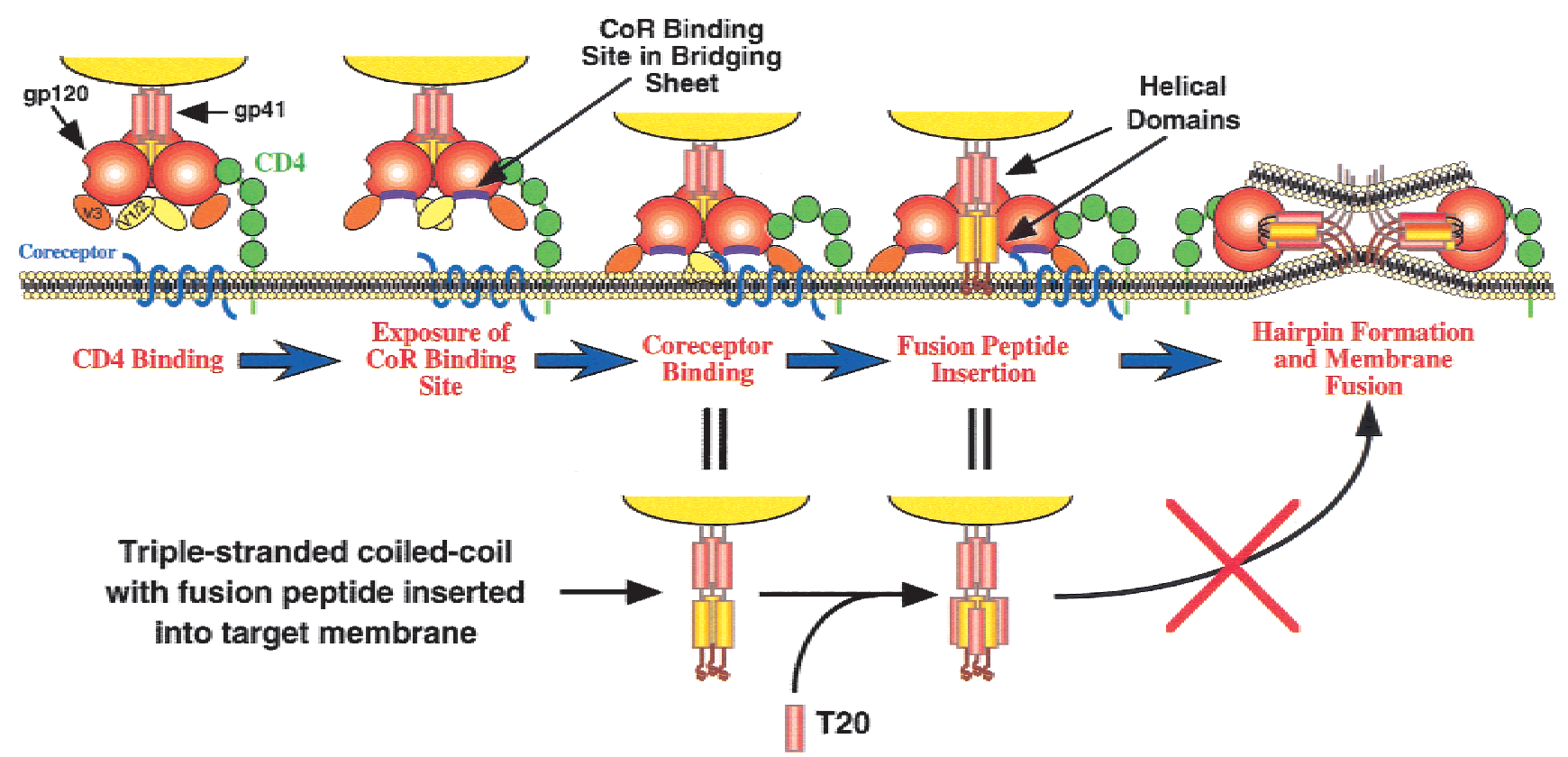

Figure 1. Model for HIV-1 entry. Binding of CD4 to gp120 results in exposure of a conserved coreceptor (CoR) binding site in gp120, perhaps by movement of the V3 and V1/2 loops. Coreceptor binding causes the fusion peptide of gp41 to be exposed and inserted into the membrane of the target cell in a triple-stranded coiled-coil. Formation of a helical hairpin structure in which gp41 folds back on itself is coincident with membrane fusion. The bottom portion of the figure displays gp41 alone. Addition of the T20 peptide blocks membrane fusion by preventing the formation of the hairpin structure.

helical domain (Wild et al. 1994, 1995). These peptides bind to the amino-terminal triple-stranded coiled-coil in gp41, blocking formation of the six-helix bundle with impressive efficiency (Fig. 1; Furuta et al. 1998). One such peptide, termed T20, has been shown to reduce virus loads in vivo by one to two orders of magnitude and is currently in Phase II clinical trials (Kilby et al. 1998). Besides peptides, small molecule inhibitors may also be able to block membrane fusion (Eckert et al. 1999; Ferrer et al. 1999). The triple-stranded coiled-coil contains a hydrophobic pocket near its carboxy-terminal end that has been shown, in principle, to be a target for small MW compounds (Eckert et al. 1999). These studies show how structural intermediates of the fusion process can be effective targets for broadly effective inhibitors.

In addition to identifying new ways to block HIV infection, identification of the viral coreceptors has also shown that virus interactions with the cell surface are highly complex, with viral tropism at the level of entry not being entirely explained by the mere presence of the appropriate cell surface receptors. For example, some X4 viruses can enter macrophages whereas others cannot (Schmidtmayerova et al. 1998; Simmons et al., 1998; Yi et al. 1998), just as only a subset of R5 SIV strains are macrophage tropic (Edinger et al. 1997a, 1999b). Other examples of restricted virus entry abound. In addition, the pathogenic potential of well-characterized SHIV (SIV/HIV chimeric viruses) and SIV isolates often maps to Env in ways that are not entirely clear and that cannot be explained solely on the basis of the types of receptors used. However, recent studies have shown that receptor density, conformation, and Env-receptor affinity may all influence viral tropism and pathogenesis, perhaps making the question of how a virus strain interacts with its receptors and the cell surface as meaningful as assigning $\mathrm{R} 5$ or X4 designations.

Membrane fusion is a cooperative process, and it is currently estimated that four to six CCR5 receptors (Kuhmann et al. 2000), multiple CD4 molecules (Layne et al. 1990), and three to six Env trimers are needed to form a fusion pore. It logically follows that virus entry will depend on receptor density and that Env-receptor affinity can impact that rate and efficiency of infection. The fact that ccr5 promoter polymorphisms and heterozygosity for the $\Delta 32$-ccr5 polymorphism are associated with altered disease course argues that relatively modest changes in receptor density can influence viral infectivity in vivo (Dean et al. 1996; McDermott et al. 1998). Studies with cell lines show that infection efficiency decreases as receptor density decreases, although the major coreceptors CCR5 and CXCR 4 still support at least some virus infection even at very low levels of expression < <1000 copies per cell; Kozak et al. 1997; Platt et al. 1998; Edinger et al. 1999a; Kuhmann et al. 2000). Receptor density can be influenced by a multitude of factors at both the macro and molecular levels. Cytokines such as interleukin-10 can result in up-regulation of coreceptor expression and enhanced viral entry (Sozzani et al. 1998), just as secretion of their cognate chemokine ligands leads to down-regulation and decreased susceptibility to infection (for review, see Lee and Montaner 1999). Receptor density could potentially be influenced by 
changes in microenvironment as well. A number of cell surface receptors can cluster in detergent insoluble, glycolipid-rich domains termed rafts (Brown and Rose 1992). In T cells, such clusters have been referred to as an immunological synapse, an area of close contact between an antigen-presenting cell and a $\mathrm{T}$ cell that results from activation of the T-cell receptor (Grakoui et al. 1999|. Concentration of receptors within an immunological synapse may stabilize low affinity interactions between the T-cell receptor and its ligands /Grakoui et al. 1999). Whether rafts may serve to concentrate viral receptors in some primary cell types is an intriguing possibility that warrants investigation. CD4 may also associate with CCR5, making virus entry more efficient, and competition between CCR5 and CXCR4 for CD4 association may help account for the preferential use of CCR5 on some cell types that express both coreceptors (Lee et al. 2000).

Just as the cooperative nature of the fusion process predicts that receptor density influences susceptibility of cells to virus infection, it can be posited that Env-receptor affinity can also influence this process. Although all Env proteins seem to bind CD4 with affinities of $<10 \mathrm{nM}$, there is considerable variation in the affinities of Env-coreceptor interactions. Whereas many R5 virus types bind to CCR5 with high affinity $(<15 \mathrm{nM}$; Doranz et al. 1999a), binding of X4 Envs to CXCR4 and R5X4 Envs to either CCR5 or CXCR4 has proven difficult to measure (Baik et al. 1999; Doranz et al. 1999b). The affinity of the prototype X4 virus strain IIIB for CXCR4 is $~ 400 \mathrm{nM}$, for example (T.L. Hoffman, unpubl.). Although a broad range of receptor affinities is compatible with infection of cell lines that typically express tens of thousands of receptor molecules, this may not be the case for primary cell types in which receptor expression levels are typically $<10,000$ per cell (Lee et al. 1999b). Because Env-coreceptor binding is reversible (Doranz et al. 1999a) and multiple Env-receptor interactions are required for fusion (Kuhmann et al. 2000), viruses with low receptor affinity are likely to fuse more slowly and inefficiently than viruses with higher binding constants. Could high affinity result in a greater ability to infect cells with low levels of receptor, enabling virus to infect a greater proportion of CD4positive cell types? It is interesting to note that alterations in a viral Env protein that increase receptor affinity without affecting the types of receptors used have been associated with markedly increased pathogenicity in a nonhuman primate model of infection (Karlsson et al. 1998).

Finally, other less well understood aspects of HIV-cell surface interactions may impact viral tropism and pathogenesis. Differences in how R5 and X4 Env proteins interact with their coreceptors have been noted (Berger et al. 1999), and in some cases Env binding to coreceptor induces receptor signaling (Davis et al. 1997; Weissman et al. 1997). Although Env-induced receptor signaling is not required for infection of transformed cell lines, it is possible that signaling in primary cells could impact postentry steps of virus replication and cell viability. As for the other seven transmembrane domain receptors, the chemokine receptors CCR5 and CXCR4 exist in distinct conformational states and are subject to a variety of posttranslational modifications, which in some cases influence virus infection (Farzan et al. 1999; Lee et al. 1999a; Chabot et al. 2000). Whether all conformations function equally well as coreceptors is not known. It is interesting to note that a small molecule inhibitor of CCR5, TAK779 (Baba et al. 1999), binds to a region of CCR5 that has thus far not been directly implicated in receptor-Env interactions (Dragic et al. 2000). Nonetheless, TAK779 blocks gp120-CCR5 binding (Dragic et al. 2000). Perhaps TAK779 prevents virus infection by altering CCR 5 conformation rather than by sterically hindering Env binding or by inducing receptor down-regulation. A similar mechanism has been reported for a small molecule inhibitor of the substance P receptor (Gether et al. 1993).

\section{During the siege: perturbations of plasma membrane homeostasis}

Once delivered inside the cell, the HIV genome is reverse transcribed and transported to the nucleus, where it integrates in the host-cell chromosome as a provirus. Viral gene expression then proceeds in two stages, first yielding the regulatory proteins Tat, Rev, and Nef, and secondly producing the late gene products Gag, Env, Vif, $\mathrm{Vpr}$ and $\mathrm{Vpu}$, or $\mathrm{Vpx}$, all involved in some aspect of virion formation. Through several of these factors, the virus toys with the homeostasis of the plasma membrane, affecting in particular the surface expression of specific receptors, including its own. Our comprehension of these phenomena is still a bit sketchy and pales in comparison with our sophisticated understanding of the mechanisms of viral entry. Nevertheless, this less mature area of HIV research has already yielded a few paradigms, for instance, how a cell can regulate the surface expression of some receptors. The HIV Nef protein plays a prominent role in these events. Abundantly produced during the earliest phase of viral gene expression, Nef is a short cytoplasmic protein recruited to membranes via amino-terminal myristoylation, a modification essential for all of its known functions. Nef impacts remarkably on the replication and survival of HIV in the body, as a subset of so-called long-term nonprogressors of HIV-1 infection harbors nef-deleted strains (Deacon et al. 1995), and nef inactivation results in viral attenuation in the SIV-rhesus macaque model (Kestler et al. 1991). From in vitro studies, it turns out that Nef is packed with functions ranging from the down-regulation of certain receptors, the perturbation of signaling pathways, and the stimulation of virion infectivity. However, determining whether one of these effects plays a predominant role in vivo has been difficult, in particular because of the lack of a fully satisfying animal model of HIV-1 infection, the difficulty of creating SIV nef point mutants that are defective in only one function, and the rapid rate of reversion of such mutants in monkeys. 


\section{MHC-I down-regulation}

Cells infected by a virus are normally recognized and eliminated by the immune system, owing in part to the surface presentation of viral peptides by proteins of the class I major histocompatibility complex (MHC-I), which allows their detection and killing by cytotoxic $\mathrm{T}$ lymphocytes. In the case of HIV, this process initially functions well, but it achieves only a temporary success. Mutational escape and possible sheltering of the virus in cellular hideouts such as resting memory $\mathrm{T}$ lymphocytes and glial cells contribute to this phenomenon, yet emerging evidence suggests that Nef-induced MHC-I down-modulation also plays an important role (Kerkau et al. 1989; Scheppler et al. 1989; Schwartz et al. 1996; Collins et al. 1998). This is not an unprecedented strategy in the realm of viruses causing chronic infections, because it is also exploited by Epstein-Barr virus, cytomegalovirus, and herpes simplex virus (Ploegh 1998; Brodsky et al. 1999).

MHC-I is the heterodimeric complex of a highly polymorphic, membrane-anchored heavy chain noncovalently associated with $\beta 2$-microglobulin $(\beta 2 \mathrm{~m})$. The assembly of the heavy chain with $\beta 2 \mathrm{~m}$ and the loading of antigenic peptides occur in the endoplasmic reticulum (ER), and only fully assembled complexes are transported to the cell surface (Bijlmakers and Ploegh 1993). In the presence of Nef, these steps appear to proceed normally at least up to the Golgi, but MHC-I is then diverted to the endosomal pathway and retrieved to the trans-Golgi network (TGN) before undergoing degradation (Schwartz et al. 1996; Greenberg et al. 1998b; Le Gall et al. 1998; Piguet et al. 2000). The cytoplasmic tail of the HLA-A heavy chain is sufficient to confer Nef responsiveness to a chimeric integral membrane protein, and in this region a tyrosine residue found in HLA-A and B but not in HLA-C plays a crucial role (Le Gall et al. 1998). The corresponding resistance of HLA-C to the effect of Nef may be physiologically relevant, because HLA-C molecules are dominant inhibitory ligands that protect cells against lysis by natural killer (NK) lymphocytes, which normally destroy cells devoid of surface MHC-I (Brutkiewicz and Welsh 1995; Parham et al. 1995; Cohen et al. 1999).

A highly conserved acidic cluster (AC) in the aminoproximal third of Nef (EEEE $\left.{ }^{65}\right)$ binds PACS-1 (phosphofurin acidic cluster sorting protein-1), the first identified member of a new family of coat proteins. PACS-1 governs the endosome-to-Golgi trafficking of furin and mannose phosphate receptor (MPR) by connecting the ACcontaining cytoplasmic domain of these molecules with the adaptor protein complex (AP-1) of endosomal clathrin-coated pits (CCPs; Wan et al. 1998). Nef binds PACS-1 in an AC-dependent manner, and this interaction is essential for MHC-1 down-regulation and TGN targeting. Furthermore, a chimeric integral membrane protein harboring Nef as its cytoplasmic domain localizes to the TGN after internalization, in an AC- and PACS-1-dependent manner (Piguet et al. 2000). This supports a model in which Nef down-regulates MHC-I by acting as a connector between the receptor cytoplasmic tail and the PACS-1 sorting pathway (Fig. 2).

An interaction between Nef and MHC-I, however, has not yet been shown, and a number of additional questions remain unanswered. For instance, how does Nef first direct MHC-I to the endosomal compartment? Remarkably, CCP-mediated endocytosis does not seem to be involved (Le Gall et al. 2000). What is the role of other determinants of Nef whose mutation abrogates MHC-I down-modulation (Fig. 3), such as an amino-terminal $\alpha$-helix and a centrally located SH3-binding prolinebased repeat located just downstream from the EEEE ${ }^{65}$ acidic cluster (Greenberg et al. 1998b; Mangasarian et al. 1999|? It is noteworthy that the TGN targeting of a CD4-Nef chimera is not prevented by mutating either one of these two other motifs, indicating that they are probably not involved in PACS-1 binding but rather in some other step necessary for MHC-I modulation (Piguet et al. 2000). Both motifs have been shown to participate in the binding of Nef to protein kinases, and the Nef proline repeat constitutes the docking site for SH3-containing Src family tyrosine kinases (Saksela et al. 1995). It could be that one such Nef-interacting protein serves as a bridge with the MHC-I cytoplasmic tail. Also, why does HIV trigger MHC-I retrieval to the TGN? All the other viruses known to down-modulate MHC-I interfere instead with MHC assembly and transport along the exocytic pathway (Ploegh 1998; Brodsky et al. 1999; Yewdell and Bennink 1999). This originality is probably functionally significant, yet for reasons that remain to be elucidated. Finally, because Nef is expressed in some forms of viral latency (Pomerantz et al. 1990), it could be that its ability to promote immune escape via MHC-I downregulation is particularly relevant in the reservoir of infected lymphocytes that persists in patients treated with highly active antiretroviral therapies (HAART). Because this cell population represents an obstacle to the eradication of the virus, anti-Nef drugs could represent useful complements to more conventional antiviral therapies.

\section{CD4 down-modulation}

Like many enveloped viruses, HIV down-regulates the cell surface expression of its cognate receptor. However, although this effect is achieved by most viruses through simple trapping of Env-receptor complexes in the ER, HIV-1 engages two additional proteins besides Env in CD4 down-modulation: Nef and Vpu (Chen et al. 1996). Why such a rage? Apparently an excess of CD4 molecules on the surface of an infected cell can be fatal to the envelope incorporation and even the release of newly formed particles (Lama et al. 1999; Ross et al. 1999). Of the three HIV-1 proteins affecting CD4, Nef acts the fastest, because it both is an early viral gene product and removes CD4 directly from the cell surface (Aiken et al. 1994; Rhee and Marsh 1994; Chen et al. 1996). In contrast, Env and Vpu are late viral proteins that target the biosynthetic pathway. Despite these nuances, Nef and $\mathrm{Vpu}$ both act as connectors that precipitate CD4 into degradation pathways. 


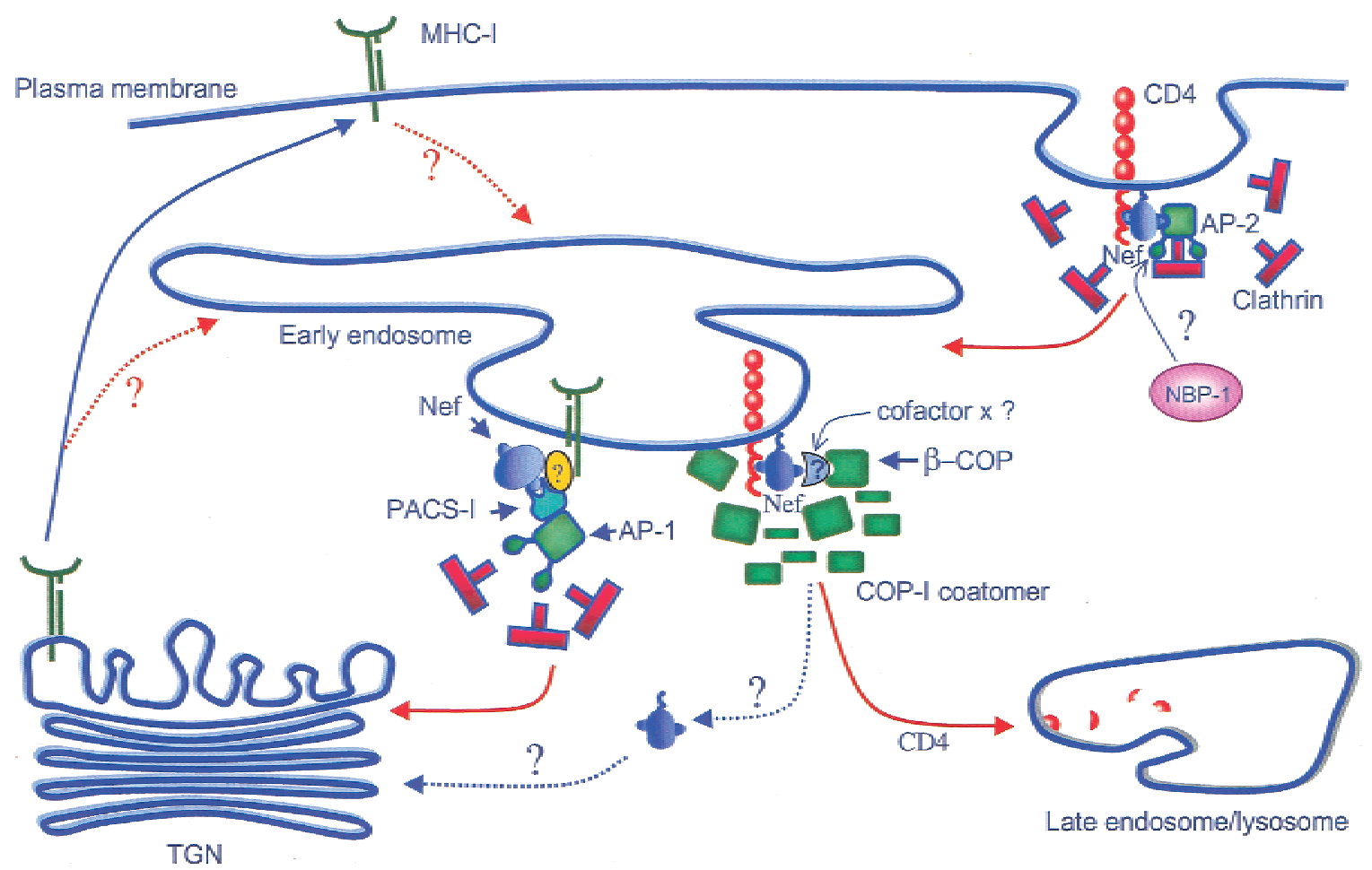

Figure 2. Model for Nef-induced MHC-I and CD4 down-modulation. Nef-induced alterations in the trafficking of MHC-I (1eft side) and CD4 (right side) are depicted with red arrows. It is possible that, after targeting CD4 to the late endosomes/lysosomes through a COP-I coatomer-mediated mechanism, Nef is retrieved to the Golgi (via PACS-1). (TGN) Trans-Golgi network; (MHC-I) class I major histocompatibility complex; (PACS-1) phosphofurin acidic cluster sorting protein-1; (AP) adaptor protein complex (of clathrin coated pits); (COP-1) coat protein-1; (NBP-1) Nef-binding protein-1 (=v-ATPase: vacuolar ATPase).

Nef-induced CD4 down-regulation is a two-step process that reflects the sequential involvement of a series of Nef-recruited components of the protein trafficking machinery (Fig. 2). At the cell surface (and to a lesser degree in the Golgi), Nef bridges the CD4 cytoplasmic tail with the adaptor protein complex of CCPs, thereby triggering the formation of CD4-specific endocytic vesicles (Schwartz et al. 1995; Foti et al. 1997; Mangasarian et al. 1997; Bresnahan et al. 1998; Craig et al. 1998; Greenberg et al. 1998a; Piguet et al. 1998; Lock et al.
Figure 3. Nef protein interactions participating in MHC-I and CD4 down-regulation. A putative three-dimensional structure of full-length Nef is drawn, reconstructed from data published by Barnham et al. (1997), Grzesiek et al. (1996a,b, 1997) and Lee et al. (1996). Alpha-helices are painted in red, beta-sheets in blue. Items concerning CD4 down-modulation are in green; those important for MHC-I regulation in brown. The myristoylation signal, essential for both functions, is in maroon.

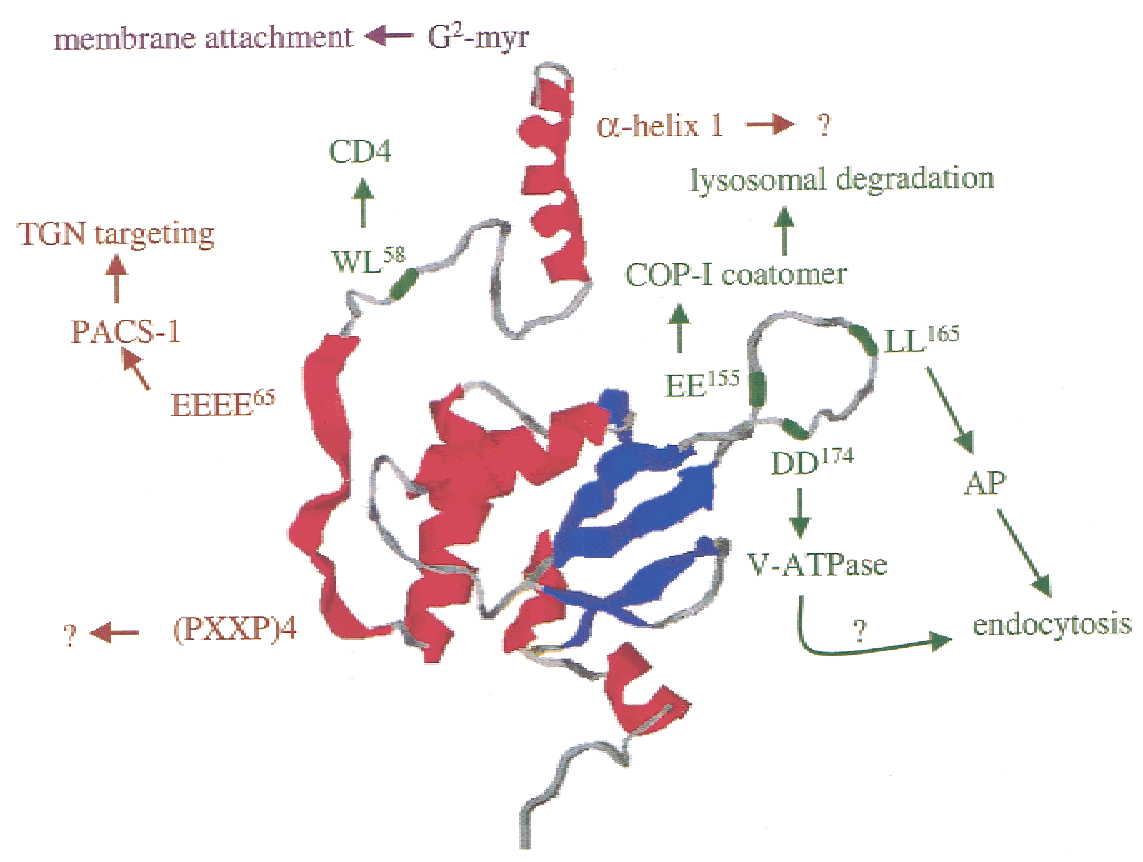


1999). Another Nef-binding protein, NBP1, which represents the catalytic subunit of a vacuolar ATPase, might consolidate the Nef-AP interaction (Lu et al. 1998). In the early endosomes, Nef then switches to another downstream partner, the COP-I coatomer, which in turn mediates the transport of CD4 to lysosomes where the receptor is degraded (Piguet et al. 1999). An interaction between Nef and the $\beta$ COP subunit of the coatomer, which seems greatly potentiated by yet unidentified additional factors, correlates with this effect (Benichou et al. 1994; Piguet et al. 1999).

In this function as well, HIV-1 Nef stands as a multivalent connector, which contains at least four distinct determinants crucial for efficient CD4 down-regulation (Fig. 3): the amino-terminal myristoylation signal for attachment to membrane; a CD4-binding domain centered on amino acids 57 to 59; a dileucine-based endocytosis signal located in a carboxy-terminal flexible loop of the viral protein, responsible for interacting with adaptor complexes perhaps with the help of the nearby V-ATPase-binding site; and another diacidic sequence just upstream of the endocytosis motif for the recruitment of COP-I in endosomes. The proximity of the APand COP-I-binding sites of Nef most probably excludes the simultaneous binding of both transporters to the viral protein. This fits well with their sequential involvement in CD4 down-regulation. In contrast, it is difficult to understand how a single molecule of Nef could interact at the same time with a chain of the CCP adaptor complex and with the V-ATPase subunit of the proton pump through determinants that are less than ten amino acids apart, considering the bulkiness of both of the macromolecular structures involved. However, recent evidence suggests that Nef might oligomerize to downregulate CD4 (Liu et al. 2000; J. Stalder and D. Trono, unpubl.). This would allow for the binding of distinct downstream partners by individual Nef monomers.

Still, one must admit that, so far, the molecular interactions that govern Nef-induced MHC-I and CD4 downregulation have been investigated mainly through a combination of genetic and functional analyses, with little biochemical and structural data if one excepts the NMR documentation of a Nef-CD4 complex (Grzesiek et al. 1996). Efforts in this direction should be intensified, as they might greatly facilitate the development of inhibitors targeting these functions of Nef.

The connector model also applies to Vpu-induced CD4 degradation, because this other HIV-1 protein targets ERtrapped CD4 molecules to the proteasome by bridging the cytoplasmic tail of the receptor with a protein known as h- $\beta$ TrCP (Bour et al. 1995; Margottin et al. 1998; Schubert et al. 1998). h- $\beta$ TrCP contains a WD repeat region, which recognizes $\mathrm{Vpu}$, and an F-box, which recruits Skplp. Skplp in turn provides a link with the ubiquitin proteolysis machinery (Margottin et al. 1998). Whether Vpu action involves dislocation of CD4 from the ER into the cytoplasm, direct attack of the cytosolic part of the glycoprotein by the proteasome, or a different, undefined mechanism remains unclear. Nevertheless, mutation of putative ubiquitination sites in the CD4 cy- toplasmic domain or thermal inactivation of the E1 ubiquitin-conjugating enzyme inhibit Vpu-induced CD4 degradation, supporting a role for the proteasome in this process (Fujita et al. 1997).

Fulfilling the prediction that Nef and Vpu must mimic the mechanisms of action of endogenous molecules responsible for linking specific targets to components of the protein trafficking machinery, several cellular proteins have been found shown to function through similar mechanisms. For instance, $\beta$-arrestin acts as a clathrin adaptor that facilitates the endocytosis of the $\beta-2$ adrenergic receptor, an event crucial for synaptic desensitization in the sympathetic nervous system (Ferguson et al. 1996). Similarly, the receptor component of the ubiquitin ligase responsible for targeting the NF-кB inhibitor $\mathrm{I} \kappa \mathrm{B} \alpha$ to the proteasome is h- $\beta \operatorname{TrCP}$, the previously identified Vpu ligand (Yaron et al. 1998).

\section{New perspectives in viral assembly and budding}

Just as virus infection requires an assemblage of proteins at the point of entry, so does budding, in which new virions emerge from the plasma membrane wrapped in a lipid bilayer and loaded with surface proteins, including Env. The viral Env and Gag proteins constitute an exceedingly small fraction of the total proteins in a cell, which creates a challenge-how are these components concentrated? HIV-1 Gag associates with the inner leaflet of the plasma membrane via its amino-terminal myristate and a cluster of basic residues near its proximal end, with the help of some more distal determinants (Zhou et al. 1994; Sandefur et al. 1998; Paillart and Göttlinger 1999). Gag also interacts with the cytoplasmic tail of gp41, the transmembrane moiety of Env (Cosson 1996). Recent work indicates that HIV may selectively bud from lipid rafts, the glycolipid-rich microdomains into which some types of proteins partition (Nguyen and Hildreth 2000). It is Gag that apparently contains the signals responsible for this targeting, whereas Env seems to be found in both raft and nonraft regions of the membrane. Nevertheless, even though viral assembly and release can occur in the absence of viral envelope, the site of budding is influenced by Env. In polarized cells in the absence of Env, HIV-1 is released from the entire cell surface; the viral glycoprotein restricts this process to the basolateral region (Owens et al. 1991). This targeting depends on the presence of an endocytosis signal in the cytoplasmic tail of gp41, pointing to a complicated set of interactions between Env, Gag, and intracellular trafficking pathways (Lodge et al. 1997; Deschambault et al. 1999|. The virus also faces a second conundrum: the terminal step of the budding process is necessarily a membrane fusion reaction. Essentially nothing is known about how HIV mediates this event, because it is independent of Env and receptors. The virus might, however, take advantage of cellular proteins normally involved in endocytosis, a process that mirrors viral budding in that it likewise necessitates membrane fusion events that pinch off small vesicles. In that respect, it is interesting that in the case of equine infectious anemia virus, an- 
other lentivirus, a YXXL motif-similar to prototypic endocytosis signals-in the carboxyl terminus of Gag has been shown to be both critical for viral release and responsible for mediating interactions with AP50, a component of the AP-2 complex that associates with clathrin-coated pits and aids in sequestering proteins in these endocytic structures (Puffer et al. 1997, 1998).

As for the steps in virus entry, virus assembly may hold important insights into viral pathogenesis. In murine cells, for example, HIV fails to assemble and bud correctly, suggesting that these cells either lack a cellular factor needed for budding or contain a factor that inhibits this process (Mariani et al. 2000). Clearly, a greater appreciation of the molecular events that describe HIV interactions with the plasma membrane will further our understanding of viral tropism and provide new therapeutic opportunities. Furthermore, it will continue to yield important information on the complicated set of interactions and biochemical processes that allow the plasma membrane to mastermind many aspects of the biology of a cell.

\section{Acknowledgments}

We thank M.Loche for the artwork and A. Piguet and V. Piguet for help with the Nef three-dimensional reconstructions.

\section{References}

Aiken, C., Konner, J., Landau, N.R., Lenburg, M.E., and Trono, D. 1994. Nef induces CD4 endocytosis: Requirement for a critical dileucine motif in the membrane-proximal CD4 cytoplasmic domain. Cell 76: 853-864.

Ashorn, P.A., Berger, E.A., and Moss, B. 1990. Human immunodeficiency virus envelope glycoprotein/CD4-mediated fusion of nonprimate cells with human cell. J. Virol. 64: 21492156.

Baba, M., Nishimura, O., Kanzaki, N., Okamoto, M., Sawada, H., Iizawa, Y., Shiraishi, M., Aramaki, Y., Okonogi, K., Ogawa, Y., et al. 1999. A small-molecule, nonpeptide CCR5 antagonist with highly potent and selective anti-HIV-1 activity. Proc. Natl. Acad. Sci. 96: 5698-5703.

Baik, S., Doms, R.W., and Doranz, B.J. 1999. HIV and SIV gp120 binding does not predict coreceptor function. Virology 259: 267-273.

Barnham, K.J., Monks, S.A., Hinds, M.G., Azad, A.A., and Norton, R.S. 1997. Solution structure of a polypeptide from the $\mathrm{N}$ terminus of the HIV protein Nef. Biochemistry 36: 59705980.

Benichou, S., Bomsel, M., Bodéus, M., Durand, H., Douté, M., Letourneur, F., Camonis, J., and Benarous, R. 1994. Physical interaction of the HIV-1 Nef protein with $\beta$-COP, a component of non-clathrin-coated vesicles essential for membrane traffic. J. Biol. Chem. 269: 30073-30076.

Berger, E.A., Doms, R.W., Fenyo, E.M., Korber, B.T.M., Littman, D.R., Moore, J.P., Sattentau, Q.J., Schuitemaker, H., Sodroski, J., and Weiss, R.A. 1998. A new classification for HIV-1. Nature 391: 240.

Berger, E.A., Murphy, P.M., and Farber, J.M. 1999. Chemokine receptors as HIV-1 coreceptors: Roles in viral entry, tropism, and disease. Annu. Rev. Immunol. 17: 657-700.

${ }^{\star}$ IR0^Bieniasz, P.D. and Cullen, B.R. 1998. Chemokine recep- tors and human immunodeficiency virus infection. Front. Biosci. 3: 44-58.

Bijlmakers, M.J. and Ploegh H.L. 1993. Putting together an MHC class I molecule. Curr. Opin. Immunol. 5: 21-26.

Bour, S., Schubert, U., Strebel, K. 1995. The human immunodeficiency virus type $1 \mathrm{Vpu}$ protein specifically binds to the cytoplasmic domain of CD4: Implications for the mechanism of degradation. J. Virol. 69: 1510-1520.

Bresnahan, P.A., Yonemoto, W., Ferrell, S., Williams-Herman, D., Geleziunas, R., and Greene, W.C. 1998. A dileucine motif in HIV-1 Nef acts as an internalization signal for CD4 downregulation and binds the AP-1 clathrin adaptor. Curr. Biol. 8: 1235-1238.

Brodsky, F.M., Lem, L., Solache, A., and Bennett, E.M. 1999. Human pathogen subversion of antigen presentation. Immunol. Rev. 168: 199-217.

Brown, D.A. and Rose, J.K. 1992. Sorting of GPI-anchored proteins to glycolipid-enriched membrane subdomains during transport to the apical surface. Cell 68: 533-544.

Brutkiewicz, R.R. and Welsh, R.M. 1995. Major histocompatibility complex class I antigens and the control of viral infections by natural killer cells. J. Virol. 69: 3967-3971.

Chabot, D.J., Chen, H., Dimitrov, D.S., and Broder, C.C. 2000. $\mathrm{N}$-linked glycosylation of CXCR4 masks coreceptor function for CCR5-dependent human immunodeficiency virus type 1 isolates. J. Virol. 74: 4404-4413.

Chan, D.C., Fass, D., Berger, J.M., and Kim, P.S. 1997. Core structure of gp41 from the HIV envelope glycoprotein. Cell 89: $263-273$.

Chan, D.C. and Kim, P.S. 1998. HIV entry and its inhibition. Cell 93: 681-684.

Chen, B.K., Gandhi, R.T., and Baltimore, D. 1996. CD4 downmodulation during infection of human $\mathrm{T}$ cells with human immunodeficiency virus type 1 involves independent activities of vpu, env, and nef. J. Virol. 70: 6044-6053.

Chesebro, B., Buller, R., Portis, J., and Wehrly, K. 1990. Failure of human immunodeficiency virus entry and infection in CD4-positive human brain and skin cells. J. Virol. 64: 215221.

Cho, M.W., Lee, M.K., Carney, M.C., Berson, J.F., Doms, R.W., and Martin, M.A. 1998. Identification of determinants on a dual-tropic human immunodeficiency virus type- 1 envelope glycoprotein that confer usage of CXCR4. J. Virol. 72: 25092515.

Choe, H., Farzan, M., Sun, Y., Sullivan, N., Rollins, B., Ponath, P.D., Wu, L., Mackay, C.R., LaRosa, G., Newman, W., et al. 1996. The $\beta$-chemokine receptors CCR3 and CCR 5 facilitate infection by primary HIV-1 isolates. Cell 85: 1135-1148.

Clapham, P.R., Blanc, D., and Weiss, R.A. 1991. Specific cell surface requirements for infection of CD4-positive cells by human immunodeficiency virus type 1, type 2 and by simian immunodeficiency virus. Virology 181: 703-715.

Cohen, G.B., Gandhi, R.T., Davis, D.M., Mandelboim, O., Chen, B.K., Strominger, J.L., Baltimore, D. 1999. The selective downregulation of class I major histocompatibility complex proteins by HIV-1 protects HIV-infected cells from NK cells. Immunity 10: 661-671.

Collins, K.L., Chen, B.K., Kalams, S.A., Walker, B.D., Baltimore, D. 1998. HIV-1 Nef protein protects infected primary cells against killing by cytotoxic T lymphocytes. Nature 391: 397-401.

Cosson, P. 1996. Direct interaction between the envelope and matrix proteins of HIV-1. EMBO J. 15: 5783-5788.

Craig, H.M., Pandori, M.W., and Guatelli, J.C. 1998. Interaction of HIV-1 nef with the cellular dileucine-based sorting pathway is required for CD4 down-regulation and optimal viral 
infectivity. Proc. Nat1. Acad. Sci. 95: 11229-11234.

Davis, C.B., Dikic, I., Unutmaz, D., Hill, C.M., Arthos, J., Siani, M.A., Thompson, D.A., Schlessinger, J., and Littman, D.R. 1997. Signal transduction due to HIV-1 envelope interactions with chemokine receptors CXCR4 or CCR5. I. Exp. Med. 186: 1793-1798.

Deacon, N.J., Tsykin, A., Solomon, A., Smith, K., Ludford, M.M., Hooker, D.J., McPhee, D.A., Greenway, A.L., Ellett, A., Chatfield, C., et al. 1995. Genomic structure of an attenuated quasi species of HIV-1 from a blood transfusion donor and recipients. Science 270: 988-991.

Dean, M., Carrington, M., Winkler, C., Huttley, G.A., Smith, M.W., Allikmets, R., Goedert, J.J., Buchbinder, S.P., Vittinghoff, E., Gomperts, E., et al. 1996. Genetic restriction of HIV-1 infection and progression to AIDS by a deletion allele of the CKR5 structural gene. Science 273: 1856-1862.

Deschambault, J., Lalonde, J.-P., Cervantes-Acosta, G., Lodge, R., Cohen, E.A., and Lemay, G. 1999. Polarized human immunodeficiency virus budding in lymphocytes involves a tyrosine-based signal and favors cell-to-cell transmission. $J$. Virol. 73: 5010-5017.

Doms, R.W. and Moore, J.P. 1998. HIV coreceptor use: A molecular window into viral tropism. In Human Retroviruses and AIDS 1998 (ed. B. Korber, B. Foley, T. Leitner, G. Myers, B. Hahn, F. McCutchan, J. Mellors, and C. Kuiken), pp. 1-12. Los Alamos National Laboratory: Theoretical Biology and Biophysics, Los Alamos, New Mexico.

Doranz, B.J., Baik, S.S.W., and Doms, R.W. 1999a. Use of a gp120 binding assay to dissect the requirements and kinetics of human immunodeficiency virus fusion events. J. Virol. 73: $10346-10358$.

Doranz, B.J., Orsini, M.J., Turner, J.D., Hoffman, T.D., Berson, J.F., Lu, Z.-H., Hoxie, J.A., Peiper, S.C., Brass, L.F., and Doms, R.W. 1999b. Identification of CXCR4 domains that support coreceptor and chemokine receptor functions. I. Virol. 73: $2752-2761$.

Dragic, T., Trkola, A., Thompson, D.A.D., Cormier, E.G., Kajumo, F.A., Maxwell, E., Lin, S.W., Ying, W., Smith, S.O., Sakmar, T.P., et al. 2000. A binding pocket for a small molecule inhibitor of HIV entry within the transmembrane helices of CCR5. Proc. Nat1. Acad. Sci. 97: 5639-5644.

Eckert, D.M., Malashkevich, V.N., Hong, L.H., Carr, P.A., and Kim, P.S. 1999. Inhibiting HIV-1 entry: Discovery of D-peptide inhibitors that target the gp41 coiled-coil pocket. Cell 99: 103-115.

Edinger, A.L., Amedee, A., Miller, K., Doranz, B.J., Endres, M., Sharron, M., Samson, M., Lu, Z.-H., Clements, J.E., Murphey-Corb, M., et al. 1997a. Differential utilization of CCR5 by macrophage and $\mathrm{T}$ cell tropic simian immunodeficiency viruses. Proc. Nat. Acad. Sci. 94: 4005-4010.

Edinger, A.L., Mankowski, J.L., Doranz, B.J., Margulies, B.J., Lee, B., Rucker, J., Sharron, M., Hoffman, T.L., Berson, J.F., Zink, C., et al. 1997b. CD4-independent, CCR5-dependent infection of brain capillary endothelial cells by neurovirulent SIV. Proc. Natl. Acad. Sci. 94: 14742-14747.

Edinger, A.L., Blanpain, C., Kunstman, K.J., Wolinsky, S.M., Parmentier, M., and Doms, R.W. 1999a. Functional dissection of CCR5 coreceptor function through the use of CD4independent simian immunodeficiency virus strains. J. Virol. 73: 4062-4073.

Edinger, A.L., Clements, J.E., and Doms, R.W. 1999b. Chemokine and orphan receptors in HIV-2 and SIV tropism and pathogenesis. Virology 260: 211-221.

Farzan, M., Mirzabekov, T., Kolchinsky, P., Wyatt, R., Cayabyab, M., Girard, N., and Girard, C. 1999. Tyrosine sulfonation of the amino terminus of CCR 5 facilitates HIV-1 en- try. Cell 96: 667-676.

Ferguson, S.S., Downey, W.E., Colapietro, A.M., Barak, L.S., Menard, L., Caron, M.G. 1996. Role of $\beta$-arrestin in mediating agonist-promoted $G$ protein-coupled receptor internalization. Science 271: 363-366.

Ferrer, M., Kapoor, T.M., Strassmaier, T., Weissenhorn, W., Skehel, J.J., Oprian, D., Schreiber, S.L., Wiley, D.C., and Harrison, S.C. 1999. Selection of gp41-mediated HIV-1 cell entry inhibitors from biased combinatorial libraries of non-natural binding elements. Nat. Struct. Biol. 6: 953-960.

Foti, M., Mangasarian, A., Piguet, V., Lew, D., Krause, K., Trono, D., and Carpentier, J.-L. 1997. Nef-mediated clathrin coated pit formation. J. Cell. Biol. 139: 37-47.

Fujita, K., Omura, S., and Silver, J. 1997. Rapid degradation of CD4 in cells expressing human immunodeficiency virus type $1 \mathrm{Env}$ and $\mathrm{Vpu}$ is blocked by proteasome inhibitors. $J$. Gen. Virol. 78: 619-625.

Furuta, R.A., Wild, C.T., Weng, Y., and Weiss, C.D. 1998. Capture of an early fusion-active conformation of gp41. Nat. Struct. Biol. 5: 276-279.

Geijtenbeek, T.B.H., Kwon, D.S., Torensma, R., van Vliet, S.J., v. Duijnhoven, G.C.F., Middel, J., Cornelissen, I.L., Nottet, H.S., Kewalramani, V.N., Littman, D.R., et al. 2000a. DCSIGN, a dendritic cell-specific HIV-1-binding protein that enhances trans-infection of T cells. Cell 100: 587-597.

Geijtenbeek, T.B.H., Torensma, R., van Vliet, S.J., van Duijnhoven, G.C.F., Adema, G.J., van Kooyk, Y., and Figdor, C.G. 2000b. Identification of DC-SIGN, a novel dendritic cellspecific ICAM-3 receptor that supports primary immune responses. Cell 100: 575-585.

Gether, U., Johansen, T.E., Snider, R.M., Lowe, J.A., Nakanishi, S., and Schwartz, T.W. 1993. Different binding epitopes on the $\mathrm{NK}_{1}$ receptor for substance $\mathrm{P}$ and a non-peptide antagonist. Nature 362: 345-347.

Grakoui, A., Bromley, S.K., Sumen, C., Davis, M.M., Shaw, A.S., Allen, P.M., and Dustin, M.L. 1999. The immunological synapse: A molecular machine controlling T cell activation. Science 285: 221-227.

Greenberg, M., DeTulleo, L., Rapoport, I., Skowronski, J., and Kirchhausen, T. 1998a. A dileucine motif in HIV-1 Nef is essential for sorting into clathrin-coated pits and for downregulation of CD4. Curr. Biol. 8: 1239-1242.

Greenberg, M.E., Iafrate, A.J., and Skowronski, J. 1998b. The SH3 domain-binding surface and an acidic motif in HIV-1 Nef regulate trafficking of class I MHC complexes. EMBO $\mathrm{.}$ 17: 2777-2789.

Grzesiek, S., Bax, A., Clore, G. M., Gronenborn, A. M., Hu, J. S., Kaufman, J., Palmer, I., Stahl, S.J., and Wingfield, P.T. 1996a. The solution structure of HIV-1 Nef reveals an unexpected fold and permits delineation of the binding surface for the SH3 domain of Hck tyrosine protein kinase. Nat. Struct. Biol. 3: 340-345.

Grzesiek, S., Stahl, S.J., Wingfield, P.T., and Bax, A. 1996b. The CD4 determinant for downregulation by HIV-1 Nef directly binds to Nef. Mapping of the Nef binding surface by NMR. Biochemistry 35: 10256-10261.

Grzesiek, S., Bax, A., Hu, J., Kaufman, J., Palmer, I., Stahl, S., Tjandra, N., and Wingfield, P. 1997. Refined solution structure and backbone dynamics of HIV-1 Nef. Protein Sci. 6: $1248-1263$.

Hernandez, L.D., Hoffman, L.R., Wolfsberg, T.G., and White, J.M. 1996. Virus-cell and cell-cell fusion. Annu. Rev. Dev. Cell. Biol. 12: 627-661.

Hoffman, T.L. and Doms, R.W. 1998. Chemokines and coreceptors in HIV/SIV-host interactions. AIDS 12: S17-S26.

Hoffman, T.L., Stephens, E., Narayan, O., and Doms, R.W. 1998. 
Human immunodeficiency virus type 1 envelope determinants of the CCR2b, CCR3, STRL33, and APJ coreceptors. Proc. Nat. Acad. Sci. 95: 11360-11365.

Hoffman, T.L., LaBranche, C., Zhang, W., Canziani, G., Robinson, J., Chaiken, I., Hoxie, J.A., and Doms, R.W. 1999. Stable exposure of the coreceptor binding site in a CD4-independent HIV-1 envelope protein. Proc. Natl. Acad. Sci. 96: 6359-6364.

Karlsson, G., Halloran, M., Schenten, D., Lee, J., Racz, P., Tenner-Racz, K., Manola, J., Gelman, R., Etemad-Moghadam, B., Desjardins, E., et al. 1998. The envelope glycoprotein ectodomains determine the efficiency of CD4+ $\mathrm{T}$ lymphocyte depletion in simian-human immunodeficiency virus-infected macaques. J. Exp. Med. 188: 1159-1171.

Kerkau, T., Schmitt-Landgraf, R., Schimpl, A., and Wecker, E. 1989. Downregulation of HLA class I antigens in HIV-1 infected cells. AIDS Res. Hum. Retroviruses 5: 613-620.

Kestler, H., Ringler, D., Mori, K., Panicali, D., and Desrosiers, R. 1991. Importance of the nef gene for maintenance of high viral loads and for development of AIDS. Cell 65: 651-662.

Kilby, J.M., Hopkins, S., Venetta, T.M., DiMassimo, B., Cloud, G.A., Lee, J.Y., Alldredge, L., Hunter, E., Lambert, D., Bolognesi, D., et al. 1998. Potent suppression of HIV-1 replication in humans by T-20, a peptide inhibitor of gp41-mediated virus entry. Nat. Med. 4: 1302-1307.

Kozak, S.L., Platt, E.J., Madani, N., Ferro, F.E., Peden, K., and Kabat, D. 1997. CD4, CXCR-4, and CCR5 dependencies for infections by primary patient and laboratory-adapted isolates of human immunodeficiency virus type 1. J. Virol. 71: 873-882.

Kuhmann, S.E., Platt, E.J., Kozak, S.L., and Kabat, D. 2000. Cooperation of multiple coreceptors for infections by human immunodeficiency virus type I. J. Virol. 74: 7005-7015.

Kwong, P.D., Wyatt, R., Robinson, J., Sweet, R.W., Sodroski, J, and Hendrickson, W.A. 1998. Structure of an HIV gp120 envelope glycoprotein in complex with the CD4 receptor and a neutralizing human antibody. Nature 393: 648-659.

LaCasse, R., Follis, K., Trahey, M., Scarborough, J., Littman, D., and Nunberg, J. 1999. Fusion-competent vaccines: Broad neutralization of primary isolates of HIV. Science 283: $357-$ 362.

Lama, J., Mangasarian, A., and Trono, D. 1999. Cell-surface expression of CD4 reduces HIV-1 infectivity by blocking Env incorporation in a Nef- and Vpu-inhibitable manner. Curr. Biol. 9: 622-631.

Lapham, C.K., Ouyang, J., Chandrasekhar, B., Nguyen, N.Y., Dimitrov, D.S., and Golding, H. 1996. Evidence for cell-surface association between Fusin and the CD4-gp120 complex in human cell lines. Science 274: 602-605.

Layne, S.P., Merges, M.J., Dembo, M.B., Spouge, J.L., and Nara, P.L. 1990. HIV requires multiple gp120 molecules for CD4mediated infection. Nature 346: 277-279.

Lee, B. and Montaner, L.J. 1999. Chemokine immunobiology in HIV-1 pathogenesis. J. Leukoc. Biol. 65: 552-565.

Lee, B., Sharron, M., Blanpain, C., Doranz, B.J., Vakili, J., Setoh, P., Berg, E., Liu, G., Guy, H.R., Durell, S.R., et al. 1999a. Epitope mapping of CCR5 reveals multiple conformational states and distinct but overlapping structures involved in chemokine and coreceptor function. I. Biol. Chem. 274: 9617-9626.

Lee, B., Sharron, M., Montaner, L.J., Weissman, D., and Doms, R.W. 1999b. Quantification of CD4, CCR5, and CXCR4 levels on lymphocyte subsets, dendritic cells, and differentially conditioned monocyte-derived macrophages. Proc. Nat. Acad. Sci. 96: 5215-5220.

Lee, C.H., Saksela, K., Mirza, U.A., Chait, B.T., and Kuriyan, J.
1996. Crystal structure of the conserved core of HIV-1 Nef complexed with a Src family SH3 domain. Cell 85: 931-942.

Lee, S., Lapham, C.K., Chen, H., King, L., Manischewitz, J., Romantseva, T., Mostowski, H. Stantchev, T.S., Broder, C.C., and Golding, H. 2000. Coreceptor competition for association with CD4 may change the susceptibility of human cells to infection with T-tropic and macrophage-tropic isolates of human immunodeficiency virus type 1. I. Virol. 74: 5016-5023.

Le Gall, S., Erdtmann, L., Benichou, S., Berlioz-Torrent, C., Liu, L., Benarous, R., Heard, J.-M., Schwarz, O. 1998. Nef interacts with the $\mu$ subunit of clathrin adaptor complexes and reveals a cryptic sorting signal in MHC-I molecules. Immunity 8: 483-495.

Le Gall, S., Buseyne, F., Trocha, A., Walker, B., Heard, J.-M., and Schwartz, O. 2000. Distinct pathways mediate Nef-induced and clathrin-dependent MHC-I downregulation. J. Virol. 74: 9256-9266.

Liu, R., Paxton, W.A., Choe, S., Ceradini, D., Martin, S.R., Horuk, R., MacDonald, M.E., Stuhlmann, H., Koup, R.A., and Landau, N.R. 1996. Homozygous defect in HIV-1 coreceptor accounts for resistance of some multiply-exposed individuals to HIV-1 infection. Cell 86: 367-377.

Liu, L.X., Heveker, N., Fackler, O.T., Arold, S., Le Gall, S., Janvier, K., Peterlin, B.M., Dumas, C., Schwartz, O., Benichou, S., et al. 2000. Mutation of a conserved residue (D123) required for oligomerization of human immunodeficiency virus type 1 nef protein abolishes interaction with human thioesterase and results in impairment of Nef biological functions. J. Virol. 74: 5310-5319.

Lock, M., Greenberg, M.E., Iafrate, A.J., Swigut, T., Muench, J., Kirchhoff, F., Shohdy, N., and Skowronski, J. 1999. Two elements target SIV nef to the AP-2 clathrin adaptor complex, but only one is required for the induction of CD4 endocytosis. $E M B O ~ J . ~ 18: 2722-2733$.

Lodge, R., Lalonde, J.-P., Lemay, G., and Cohen, E.A. 1997. The membrane-proximal intracytoplasmic residue of HIV-1 envelope glycoprotein is critical for basolateral targeting of viral budding in MDCK cells. EMBO J. 16: 101-111.

Lu, X., Yu, H., Liu, S., Brodsky, F.M., and Peterlin, B.M. 1998. Interactions between HIV1 Nef and vacuolar ATPase facilitate the internalization of CD4. Immunity 8: 647-656.

Maddon, P.J., Dalgleish, A.G., McDougal, J.S., Clapham, P.R., Weiss, R.A., and Axel, R. 1986. The T4 gene encodes the AIDS virus receptor and is expressed in the immune system and the brain. Cell 47: 333-348.

Mangasarian, A., Foti, M., Aiken, C., Chin, D., Carpentier, J.L., and Trono, D. 1997. The HIV-1 Nef protein acts as a connector with sorting pathways in the Golgi and at the plasma membrane. Immunity 6: 67-77.

Mangasarian, A., Piguet, V., Wang, J.K., Chen, Y., Trono, D. 1999. Nef-induced CD4 and major histocompatibility complex class I (MHC-I) down-regulation are governed by distinct determinants: $\mathrm{N}$-terminal $\alpha$-helix and proline repeat of Nef selectively regulate MHC-I trafficking. J. Virol. 73: 1964-1973.

Margottin, F., Bour, S.P., Durand, H., Selig, L., Benichou, S., Richard, V., Thomas, D., Strebel, K., Benaroos, R. 1998. A novel human WD protein, h-bTrCp, that interacts with HIV-1 Vpu connects CD4 to the ER degradation pathway through an F-box motif. Mol. Cell 1: 565-574.

Mariani, R., Rutter, G., Harris, M.E., Hope, T.J., Krausslich, H.G., Landau, N.R. 2000. A block to human immunodeficiency virus type 1 assembly in murine cells. J. Virol. 74: 3859-3870.

Martin, K.A., Wyatt, R., Farzan, M., Choe, H., Marcon, L., Des- 
jardins, E., Robinson, J., Sodroski, J., Gerard, C., and Gerard, N.P. 1997. CD4-independent binding of SIV gp120 to rhesus CCR5. Science 278: 1470-1473.

McDermott, D.H., Zimmerman, P.A., Guignard, F., Kleeberger, C.A., Leitman, S.F., and Murphy, P.M. 1998. CCR5 promoter polymorphism and HIV-1 disease progression. Lancet 352: 866-870.

Melikyan, G.B., Markosyan, R.M., Hemmati, H., Delmedico, M.K., Lambert, D.M., and Cohen, F.S. 2000. The transition of HIV-1 gp41 into a six-helix bundle configuration induces membrane fusion. J. Cell. Biol. (in press).

Miedema, F., Meyaard, L., Koot, M., Klein, M.R., Roos, M.T.L., Groenink, M., Fouchier, R.A.M., Van't Wout, A.B., Tersmette, M., Schellekens, P.T.A., et al. 1994. Changing virushost interactions in the course of HIV-1 infection. Immunol. Rev. 140: 35-72.

Nguyen, D.H. and Hildreth, J.E.K. 2000. Evidence for budding of human immunodeficiency virus type 1 selectively from glycolipid-enriched membrane rafts. J. Virol. 74: 3264-3272.

Owens, R.J., Dubay, J.W., Hunter, E., Compans, R.W. 1991. Human immunodeficiency virus envelope protein determines the site of virus release in polarized epithelial cells. Proc. Natl. Acad. Sci. 88: 3987-3991.

Paillart, J.-C. and Göttlinger, H.G. 1999. Opposing effects of human immunodeficiency virus type 1 matrix mutations support a myristyl switch model of Gag membrane targeting. J. Virol. 73: 2604-2612.

Parham, P., Adams, E.J., and Arnett, K.L. 1995. The origins of HLA-A,B,C polymorphism. Immunol. Rev. 143: 141-180.

Piguet, V., Chen, Y.-L., Mangasarian, A., Foti, M., Carpentier, J.-L., Trono, D. 1998. Mechanism of Nef induced CD4 endocytosis: Nef connects CD4 with the $\mu$ chain of adaptor complexes. EMBO J. 17: 2472-2481.

Piguet, V., Gu, F., Foti, M., Demaurex, N., Gruenberg, J., Carpentier, J.-L., Trono, D. 1999. Nef-induced CD4 degradation: A diacidic-based motif in Nef functions as a lysosomal targeting signal through the binding of $\beta$-COP in endosomes. Cell 97: 63-73.

Piguet, V., Wan, L., Borel, C., Mangasarian, A., Demaurex, N., Thomas, G., Trono, D. 2000. HIV-1 Nef protein binds to the cellular protein PACS-1 to downregulate class I major histocompatibility complexes. Nat. Cell Biol. 2: 163-167.

Platt, E.J., Wehrly, K., Kuhmann, S.E., Chesebro, B., and Kabat, D. 1998. Effects of CCR5 and CD4 cell surface concentrations by macrophage-tropic isolates of human immunodeficiency virus type 1. J. Virol. 72: 2855-2864.

Ploegh, H.L. 1998. Viral strategies of immune evasion. Science 280: $248-253$.

Poirier, M.A., Xiao, W., Macosko, J.C., Chan, C., Shin, Y.K., and Bennett, M.K. 1998. The synaptic SNARE complex is a parallel four-stranded helical bundle. Nat. Struct. Biol. 5: 765769.

Pomerantz, R., Trono, D., Feinberg, M., and Baltimore, D. 1990. Cells nonproductively infected with HIV-1 exhibit an aberrant pattern of viral RNA expression: A molecular model for latency. Cell 61: 1271-1276.

Puffer, B.A., Parent, L.J., Wills, J.W., and Montelaro, R.C. 1997. Equine infection anemia virus utilizes a YXXL motif in the late assembly domain of the Gag p9 protein. I. Virol. 71: 6541-6546.

Puffer, B.A., Watkins, S., and Montelaro, R.C. 1998. Identification of an interaction between EIAV Gag p9 protein and cellular AP-2 complex that is critical for virus assembly. $J$. Virol. 72: 10218-10221.

Reeves, J., Hibbitts, S., Simmons, G., McKnight, A., AzevedoPereira, J., Moniz-Pereira, J., and Clapham, P. 1999. Primary human immunodeficiency virus type 2 (HIV-2) isolates infect CD4-negative cells via CCR5 and CXCR4: Comparison with HIV-1 and simian immunodeficiency virus and relevance to cell tropism in vivo. J. Virol. 73: 7795-7804.

Reitter, J.N., Means, R.E., and Desrosiers, R.C. 1998. A role for carbohydrates in immune evation in AIDS Nat. Med. 4: 679684.

Rhee, S.S. and Marsh, J.W. 1994. Human immunodeficiency virus type 1 Nef-induced down-modulation of CD4 is due to rapid internalization and degradation of surface CD4. J. Virol. 68: 5156-5163.

Rizzuto, C.D., Wyatt, R., Hernandez-Ramos, N., Sun, Y., Kwong, P.D., Hendrickson, W.A., and Sodroski, J. 1998. A conserved HIV gp120 glycoprotein structure involved in chemokine receptor binding. Science 280: 1949-1953.

Ross, T.M., Oran, A.E., and Cullen, B.R. 1999. Inhibition of HIV-1 progeny virion release by cell-surface CD4 is relieved by expression of the viral nef protein. Curr. Biol. 9: 613-621.

Saksela, K., Cheng, G., and Baltimore, D. 1995. Proline-rich (PxxP) motifs in HIV-1 Nef bind to SH3 domains of a subset of Src kinases and are required for the enhanced growth of $\mathrm{Nef}+$ viruses but not for down-regulation of CD4. EMBO T. 14: 484-491.

Samson, M., Libert, F., Doranz, B.J., Rucker, J., Liesnard, C., Farber, C.-M., S. Saragosti, S., Lapoumèroulie, C., Cogniaux, J., Forceille, C., et al. 1996. Resistance to HIV-1 infection of Caucasian individuals bearing mutant alleles of the CCR5 chemokine receptor gene. Nature 382: 722-725.

Sandefur, S., Varthakavi, V., and Spearman, P. 1998. The I domain is required for efficient plasma membrane binding of human immunodeficiency virus type $1 \mathrm{Pr} 55^{\mathrm{Gag}}$. I. Virol. 72: $2723-2732$.

Scheppler, J., Nicholson, J., Swan, D., Ahmed-Ansari, A., McDougal, J. 1989. Downmodulation of MHC-I in a CD4+ T cell line, CEM-E5 after HIV-1 infection. J. Immunol. 143: $2858-2866$

Schmidtmayerova, H., Alfano, M., Nuovo, G., and Burkinsky, M. 1998. Human immunodeficiency virus type 1 T-lymphotropic strains enter macrophages via a CD4- and CXCR4mediated pathway: Replication is restricted at a postentry level. J. Virol. 72: 4633-4642.

Schubert, U., Anton, L.C., Bacik, I., Cox, J.H., Bour, S., Bennink, J.R., Orlowski, M., Strebel, K., Yewdell, J.W. 1998. CD4 glycoprotein degradation induced by human immunodeficiency virus type $1 \mathrm{Vpu}$ protein requires the function of proteasomes and the ubiquitin-conjugating pathway. J. Virol. 72: 2280-2288.

Schwartz, O., Dautry-Varsat, A., Goud, B., Marechal, V., Subtil, A., Heard, J.M., Danos, O. 1995. Human immunodeficiency virus type 1 Nef induces accumulation of CD4 in early endosomes. J. Virol. 69: 528-533.

Schwartz, O., Maréchal, V., Le Gall, S., Lemonnier, F., Heard, J.M. 1996. Endocytosis of major histocompatibility complex class I molecules is induced by the HIV-1 Nef protein. Nat. Med. 2: 338-342.

Simmons, G., Reeves, J.D., McKnight, A., Dejucq, N., Hibbitts, S., Power, C.A., Aarons, E., Schols, D., De Clerq, E., Proudfoot, A.E.I., et al. 1998. CXCR4 as a functional coreceptor for human immunodeficiency virus type 1 infection of primary macrophages. J. Virol. 72: 8453-8457.

Skehel, J.J. and Wiley, D.C. 1998. Coiled coils in both intracellular and viral membrane fusion. Cell 95: 871-874.

Sozzani, S., Ghezzi, S., Iannolo, G., Luini, W., Borsatti, A., Polentarutti, N., Sica, A., Locati, M., Mackay, C., Wells, T.N.C., et al. 1998. Interleukin 10 increases CCR5 expression and HIV infection in human monocytes. J. Exp. Med. 
187: 439-444.

Sutton, R.B., Fasshauer, D., Jahn, R., and Brunger, A.T. 1998. Crystal structure of a SNARE complex involved in synaptic exocytosis at $2.4 \AA$ resolution. Nature 395: 347-353.

Trkola, A., Drajic, T., Arthos, J., Binley, J.M., Olson, W.C., Allaway, G.P., Cheng-Mayer, C., Robinson, J., Maddon, P.J., and Moore, J.P. 1996. CD4-dependent, antibody-sensitive interactions between HIV-1 and its coreceptor CCR-5. Nature 384: 184-187.

Wan, L., Molloy, S.S., Thomas, L., Liu, G., Xiang, Y., Rybak, S.L., Thomas, G. 1998. PACS-1 defines a novel gene family of cytosolic sorting proteins required for trans-Golgi network localization. Cell 94: 205-216.

Weissenhorn, W., Dessen, A., Harrison, S.C., Skehel, J.J., and Wiley, D.C. 1997. Atomic structure of the ectodomain from HIV-1 gp41. Nature 387: 426-430.

Weissman, D., Rabin, R.L., Arthos, J., Rubbert, A., Dybul, M., Swofford, R., Venkatesan, S., Farber, J.M., and Fauci, A.S. 1997. Macrophage-tropic HIV and SIV envelope proteins induce a signal through the CCR5 chemokine receptor. Nature 389: 981-985.

Wild, C., Greenwell, T., Shugars, D., Rimsky-Clarke, L., and Matthew, T. 1995. The inhibitory activity of an HIV type 1 peptide correlates with its ability to interact with a leucine zipper structure. AIDS Res. Hum. Retroviruses 11: 323-325.

Wild, C.T., Shugars, D.C., Greenwell, T.K., McDanal, C.B., and Matthews, T.J. 1994. Peptides corresponding to a predictive a-helical domain of human immunodeficiency virus type 1 gp4l are potent inhibitors of virus infection. Proc. Natl. Acad. Sci. 91: 9770-9774.

Wu, L., Gerard, N.P., Wyatt, R., Choe, H., Parolin, C., Ruffing, N., Borsetti, A., Cardoso, A.A., Desjardin, E., Newman, W., et al. 1996. CD4-induced interaction of primary HIV-1 gp120 glycoproteins with the chemokine receptor CCR-5. Nature 384: 179-183.

Wyatt, R. and Sodroski, J. 1998. The HIV-1 envelope glycoproteins: Fusogens, antigens, and immunogens. Science 280: 1884-1888.

Yaron, A., Hatzubai, A., Davis, M., Lavon, I., Amit, S., Manning, A.M., Andersen, J.S., Mann, M., Mercurio, F., Ben-Neriah, Y. 1998. Identification of the receptor component of the Iк-B $\alpha$ ubiquitin ligase. Nature 396: 590-594.

Yewdell, J.W. and Bennink, J.R. 1999. Mechanisms of viral interference with MHC class I antigen processing and presentation. Annu. Rev. Cell. Dev. Biol. 15: 579-606.

Yi, Y., Rana, S., Turner, J.D., Gaddis, N., and Collman, R.G. 1998. CXCR4 is expressed by primary macrophages and supports CCR5-independent infection by dual-tropic but not Ttropic isolates of HIV-1. J. Virol. 72: 772-777.

Zhou, W., Parent, L.J., Wills, J.W., and Resh, M.D. 1994. Identification of a membrane-binding domain within the aminoterminal region of human immunodeficiency virus type 1 Gag protein which interacts with acidic phospholipids. I. Virol. 68: 2556-2669. 


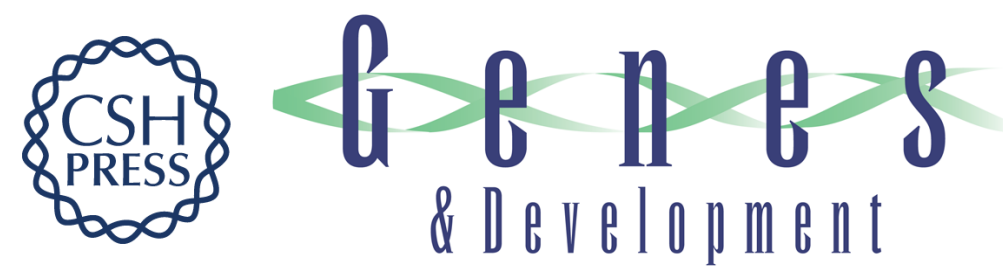

\section{The plasma membrane as a combat zone in the HIV battlefield}

Robert W. Doms and Didier Trono

Genes Dev. 2000, 14:

Access the most recent version at doi:10.1101/gad.833300

References This article cites 129 articles, 62 of which can be accessed free at: http://genesdev.cshlp.org/content/14/21/2677.full.html\#ref-list-1

License

Email Alerting Receive free email alerts when new articles cite this article - sign up in the box at the top Service right corner of the article or click here.

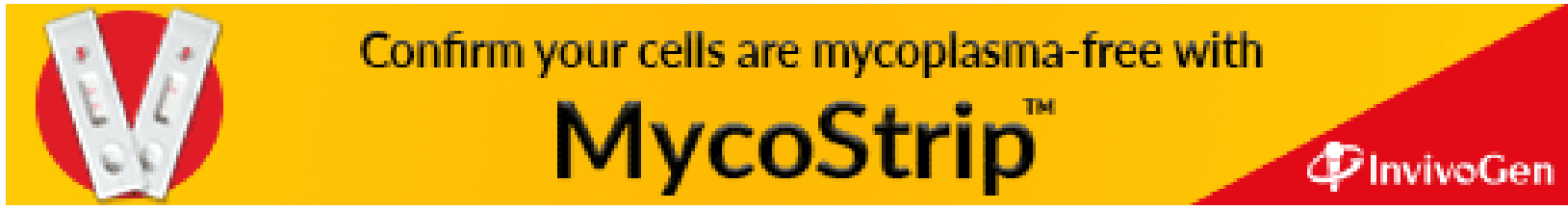

